\title{
Government and Non Governmental Organization (NGO) Relation on Protection of Child Labor In East Java, Indonesia
}

\author{
A Study of Sanggar Alang-Alang, Yayasan Arek Lintang, and Lembaga Pengkajian \\ Kemasyarakatan dan Pembangunan
}

\author{
Amelia Ayang Sabrina \\ Department of Administrative Science \\ Universitas Indonesia \\ Depok, Indonesia \\ ayangamelia@gmail.com
}

\author{
Kusnar Budi \\ Department of Administrative Science \\ Universitas Indonesia \\ Depok, Indonesia \\ budikusnar@yahoo.co.id
}

\begin{abstract}
This study discusses the GO-NGO relation for child labor protection in East Java, Indonesia. The study uses qualitative approach through in-depth interviews and literature studies. The results show that the GO-NGO relation is characterized by pragmatic relation and the NGOs have the tendency to become government's sub contract in protection program. This relation also affects how NGO behave to the government; it is different in each NGO based on its point of view and orientation. Such relation indicates the lack of political will and capacity of the governmental bodies. Furthermore, this relation can also be explained in terms of child labor issue which is still considered as private rather than public issue. Furthermore, the study reveals that to have a bearing on the child labor itself, intervention does not only goes for the child, it must also shift child labor issue from private to public issue; a focus on society circle above the child is an important perspective to effective policy.
\end{abstract}

Keywords: $\mathrm{GO}-\mathrm{NGO}$ relation, $\mathrm{NGO}$, societal governance, child protection, child labor

\section{INTRODUCTION}

The high rate of poverty and unemployment still become dilemma and justification for the existence of child labor in developing country. Even in some regions, this issue was supported by the tradition and cultural values, hence making child labor a common social phenomenon, accepted as a 'harsh reality'. Moreover, children issue is still considered as a domestic issue. Family is considered as the only one having the authority over the children and there is nothing the public can do. Therefore, most covert child labor consists of activities conducted for and under the direct supervision of the child's parents (such as helping at home, working in the family farm, and contributing to the family business) (Cigno, 2011). Even though, children are regarded as the vulnerable group within the society. Their rights have higher possibility of being violated; therefore the state has to give more protection to it.

The government and international development agencies in developing countries recognize that human investment, more than capital accumulation, is the mainspring of economic and civil progress. In fact, many children in poor developing countries fail to complete even primary education, due to being imposed to work. With such vulnerability, child labor is even vicious because children may be incapable to protect their own right, hence dependent on the adults. Therefore, child labor is still an important issue in developing countries.

The dilemma caused by the existence of child labor also prevails in Indonesia. As one of the countries with the largest number of child labor in the South-East Asia, along with Cambodia (UNICEF.org, 2007), the government said that at least there are 500,000 child labors at the age of 15-17 each year in 2011-2015; the highest amount of which reached 949,584 in 2012. Child labor in Indonesia spreads in many Provinces. The government counts that provinces in Java are those with the largest number of child labors, aged 15-17 years. It shows that the largest amount of child labors yearly is found in West Java Province, while East Java is the third largest. The number of child labor in East Java far exceeds those of other provinces outside Java which are less than 30,000 children, except for South Sulawesi, reaching 31,394 children employed on August 2014 (Ministry of Manpower of the Republic of Indonesia, 2016).

In addition to the high number of children employed in Indonesia, the working conditions of these children are also heartbreaking. Further studies show that as many as $20 \%$ of children employed in Indonesia work more than 15 hours a day, and $99 \%$ of them do not even have a day off (DOL.gov, 2014). Children are also prone to experiencing the impact of the work done in terms of health, as well as physical and psychological securities. Although the amount appears to show a decline in 2011-2015, its covert locations and the ease to change the status cause the number of children involved in employment possibly expand much more and in various forms.

Child labor phenomenon both in Indonesia and Java cannot be separated from the influence of other actors in their environment. Children's family and social environment are closer to the children than take place macro agencies or the government. Child labor may take place when the high rate of poverty forces children in a poor family to pursue their 
economic values. This perception is accommodated in Javanese culture, thus customarily justified. There is "Ngenger" tradition within Javanese culture, meaning a child from a poor family is commonly sent to his more-established relatives or extended family in cities; the child may also be entrusted to a family who do not have any blood-relationship yet willing to raise the child (ILO, 2004). The purpose of "Ngenger" is to guarantee that the child get shelter and living accommodation plus education; nevertheless in return, the child must help with various household work or simply be a household worker for the family.

This condition is also supported by Indonesian legal product that still allowing children to work in certain conditions that must be safe for them. However in practice, weak law enforcement and awareness in the society make the policy itself vulnerable in various vital sectors, including the lack of stakeholder awareness, inaccurate data collection, sluggish operational actions, and poor coordination of cross-sectoral cooperation (National Committee of RAN PBPTA, no year). Later the National Committee, however, learn that in the implementation of child labor protection policies, the state should engage NGOs since local NGOs are closer to the society and easier to reach the child itself. Such social power makes them easier to take direct actions toward child labors. This is in line with the opinion of Bronfenbenner (1979) stating that community system is the closest layer to children after family, while state and other macro actors are the furthest one. The role of the NGOs who work within society and the child environment is capable to become an influential actor for the reduction of child labors and protection of children. NGOs can complement for government's shortages and become the organized, constant key actors while collaborating with the government. Therefore, the GO-NGOs relation in the case of child labor protection becomes an important issue for the acceleration of child labor eradication.

The condition of GO-NGOs relation in East Java is unique. East Java Province is considered to have more commitments and instruments to support child labor protection than other provinces in Java as well as big support from the local NGOs. East Java Province becomes the province with the fastest and the highest ratio of regional action committee for RAN PBPTA (one of child eradication program). Of the 38 districts/cities in East Java, there are 36 district/municipal action committees; in the meanwhile Central Java has 11 districts committees out of 35 districts/municipalities; while West Java only has 5 district committees (JARAK, 2010). East Java is also one of the 7 provinces implementing the PPA-PKH program in 2017 with a total 30 shelters, safeguarding as many as 900 child labors (Ministry of Manpower of the Republic of Indonesia, 2016).

On the other hand, at least as many as 8 NGOs are involved in RAN-PBPTA program in East Java Province. The target group varies from children involved in formal and non-formal employment as well as to varied working areas both in certain cities and throughout East Java Province. Among the 8 NGOs, 3 of them are Child Protection Institutions initiated by ILO and the government while the rest is local initiated NGOs. These NGOs work with different targets and forms for both children employed in the formal and informal sectors.
The implementation of child labor protection in East Java has greatly involved and relied on NGOs. This can be seen in the development of direct action programs that are part of RANPBPTA, where all direct action programs involve NGOs (JARAK, 2010). Great efforts from both sides in East Java are potential to build effective GO-NGOs relationship in order to accelerate the protection of child labor. But in fact, these efforts have not shown significant changes in the reduction of child labor and protection of children; East Java is still the third highest in the amount of child labor in Indonesia. In 2013-2015, the number of child labor was still above 60,000 children. On August 2013 it reached 78,080; on August 2014 it reached 70,179; and on August 2015 reaching 64,162 children. Therefore, it is important to examine how is the actual situation and problem in the GO-NGOs relation specifically in East Java to answer the reason behind the high number of child labors.

Due to the importance, the situation can be seen in three ways. First, the government, NGOs, and family as the external actor influence the children's work as conceptualized by Uri Brofenbenner's under social ecology theory. Second, the GONGOs relation as perceived by Philip Eldridge's theory of Government and NGO relation in Indonesia. Third, the government governs societal development and societal issues. Jan Kooiman's theory about Societal Governance is also used to explain the situation through his analysis in social-political interactions between the government, NGOs, and the society itself. This GO-NGOs relation would reveal governance as the instrument to conceptualize problems and opportunities, and the context of borderline with another actor, i.e. NGOs. In the end, this article would reveal the relation between the government and NGO on child labor protection in East Java.

\section{Methodology}

The approach taken in this research is qualitative approach. This approach is used by researchers to build the meaning of a phenomenon from the views of participants (Cresswell, 2014). This approach is used due to their contexts on the borderline between the social and political-or in current terms, the borderline between state, market, and civil society. Child labor is considered as covert and unpopulist issue; thus largely contextual, requiring a bigger picture of reality rather than checking on theories. The technique used by the Authors in the primary data collection process is to conduct in-depth interviews. In-depth interviews actually involve quiet wide actors since some of the child labors are considered as social welfare problems (PMKS), making the Minister of Social Affairs as a person in charge, while others are considered as illegal workers at industries, making the Minister of Manpower as the person responsible. Therefore, to collect perspective from the Office for Social Affairs (Dinsos) of East Java Province, indepth interviews were conducted with the Division for Child Social Rehabilitation. On the other hand, to see the child labor in industries, an interview was conducted with the Directorate for Women and Child Norm Supervision of the Ministry of Manpower (Menaker).

Meanwhile the NGOs is divided by two: the one working on informal child labor (such as street child) is represented by NGO Sanggar Alang-Alang and Arek Lintang; and that on formal child labor (working in companies) is represented by 
Agency for Social and Development Study (LPKP). Perspective from academicians are also taken. The location of the study was in Surabaya, Malang, and Jakarta with the data collection time on 3-31 May 2017. The secondary data collection is through literature study by studying data related to the relation of government and NGO in the protection of child labor in East Java.

\section{RESULT}

These NGOs is divided by two classifications of child labor: children involved in informal work areas (street child) are taken care of by Alang-Alang and Arek Lintang and children involved in formal work areas (farm and plantation) are taken care of by LPKP. GO-NGO relation for child labor protection in each working area involves the relation of various and different government actors. Every kind of relation, in the form of both government program and other kind of relation, makes different actions and imposes different perception to each NGOs, yet shows a particular pattern. This can be understood by considering the costs and benefits of co-operation from the respective standpoint of government and NGOs (Eldridge, 1996).

Alang-Alang, as a NGO based on Surabaya and focusing in street child protection, started their movement at 1998. The founder, H. Didit Hape said that the initiative of relation with the government began after well-known mass media blew up his organization. The initiative was taken by East Java Office for Social Affairs due to the exposure of the media which appreciated Alang-Alang of its unique way of street children empowerment: through music and arts. The relation continues with the government initiative to propose the "Rumah Singgah" program. Rumah Singgah is basically a national program initiated by the government, due to the high rate of street child and homeless people because of 1998 monetary crisis. Later, the direct relation is also made when Office for Social Affairs gave funds through TEPAK program and work equipment for the children, furthered by the experience of communicating with the Surabaya City Office.

H. Didit Hape views Rumah Singgah as merely a facility for the street child to rest and go back to work. Although in the end H. Didit Hape still admitting Alang-Alang as one of many Rumah Singgahs in Surabaya, in this relationship Alang-Alang performs a critical collaboration as explained by Philip Eldridge's (1996) view in second stream model. Alang-Alang does not only take the program for granted but also shows their stance against the program and adjust it. Because of that, AlangAlang too shows a critical view when the Office for Social Affairs of East Java gave them funds in the form of money and equipment through TEPAK program; but it did not based on their needs. The money they receive was given unexpectedly and not routine, making it hard to manage in order to support the well-being of street children effectively. The aid is also contradictory with Alang-Alang's stance that wants to support total eradication of child labor. Particularly for the aid in the form of work equipment, Alang-Alang received an amount of compressor (street tire-reparation machine) and sewing machine for the children. It clearly even worse because it supports the children to keep working meanwhile child labor must be eradicated. Further conclusion of each stance and mobilization of NGOs and how the relation is going is shown by Table 1 below.

TABLE I GO-NGO RELATION

\begin{tabular}{|c|c|c|c|c|}
\hline NGO & \multicolumn{2}{|c|}{$\begin{array}{l}\text { NGO Perspective on Child } \\
\text { Labor }\end{array}$} & $\begin{array}{l}\text { Relation } \\
\text { Aspect with } \\
\text { the } \\
\text { Government } \\
\text { (Philip } \\
\text { Eldridge, } \\
\text { 1996) }\end{array}$ & $\begin{array}{l}\text { GO and NGO } \\
\text { Perspective on GO- } \\
\text { NGO Relation }\end{array}$ \\
\hline \multirow[t]{2}{*}{$\begin{array}{l}\text { Alang- } \\
\text { Alang }\end{array}$} & $\begin{array}{l}\text { NGO } \\
\text { stance }\end{array}$ & $\begin{array}{l}\text { Pro child labor } \\
\text { eradication and } \\
\text { pro child right of } \\
\text { interest and talent }\end{array}$ & $\begin{array}{l}\text { Stance vs. } \\
\text { Official } \\
\text { Develop- } \\
\text { ment } \\
\text { Programs }\end{array}$ & $\begin{array}{c}\text { Critical } \\
\text { collaboration }\end{array}$ \\
\hline & $\begin{array}{l}\text { NGO } \\
\text { mobiliza } \\
\text { tion }\end{array}$ & $\begin{array}{l}\text { Direct action } \\
\text { towards street } \\
\text { child through art } \\
\text { and ethical } \\
\text { education }\end{array}$ & $\begin{array}{l}\text { Orientation } \\
\text { vs. State } \\
\text { Structure }\end{array}$ & Accommodate \\
\hline \multirow[t]{2}{*}{$\begin{array}{c}\text { Yayasan } \\
\text { Arek } \\
\text { Lintang }\end{array}$} & $\begin{array}{l}\text { NGO } \\
\text { stance }\end{array}$ & $\begin{array}{l}\text { Pro child labor } \\
\text { eradication; } \\
\text { promoting } 5 \\
\text { cluster of child } \\
\text { rights; believe that } \\
\text { NGO substitute } \\
\text { the absence of the } \\
\text { GO }\end{array}$ & $\begin{array}{l}\text { Stance vs. } \\
\text { Official } \\
\text { Develop- } \\
\text { ment } \\
\text { Programs }\end{array}$ & $\begin{array}{l}\text { Critical } \\
\text { collaboration at } \\
\text { first but later avoid } \\
\text { involvement and } \\
\text { tends to oppose }\end{array}$ \\
\hline & $\begin{array}{l}\text { NGO } \\
\text { mobiliza } \\
\text { tion }\end{array}$ & $\begin{array}{c}\text { Direct action } \\
\text { towards street } \\
\text { child and focused } \\
\text { on right protection }\end{array}$ & $\begin{array}{l}\text { Orientation } \\
\text { vs. State } \\
\text { Structure }\end{array}$ & $\begin{array}{l}\text { Accommodate at } \\
\text { first but later } \\
\text { become opposing } \\
\text { and maintaining } \\
\text { distance }\end{array}$ \\
\hline \multirow[t]{2}{*}{ LPKP } & $\begin{array}{l}\text { NGO } \\
\text { stance }\end{array}$ & $\begin{array}{l}\text { Pro } r \text { child } \\
\text { labor eradication } \\
\text { and pro GO } \\
\text { program }\end{array}$ & $\begin{array}{l}\text { Stance vs. } \\
\text { Official } \\
\text { Develop- } \\
\text { ment } \\
\text { Programs }\end{array}$ & $\begin{array}{c}\text { Co-operate with } \\
\text { GO }\end{array}$ \\
\hline & $\begin{array}{l}\text { NGO } \\
\text { mobiliza } \\
\text { tion }\end{array}$ & $\begin{array}{l}\text { Direct program } \\
\text { and collaborate } \\
\text { with GO }\end{array}$ & $\begin{array}{l}\text { Orientation } \\
\text { vs. State } \\
\text { Structure }\end{array}$ & $\begin{array}{l}\text { Accommodate the } \\
\text { GO program }\end{array}$ \\
\hline
\end{tabular}

Another relation is made by the Surabaya city government, especially Mayor of Surabaya and Department of Population and Civil Registration of Surabaya. The Government of Surabaya City makes relation with Alang-Alang through Street Art Festival Program, awards for related figures, and NGOs in Surabaya, as well as the informal relationship of the founder of Alang-Alang with the Mayor of Surabaya, Tri Rismaharini that leads to special bureaucratic access. This special bureaucratic access is the legitimacy for Alang-Alang to act as the representative of the street children's family who mostly do not have birth certificate due to various background they have. Birth certificate is important for the children in order to have access to public facilities such as school, economic aids, and others. 
On the other hand, unlike Alang-Alang, the actors associated with the Arek Lintang include Surabaya Police Department, Office for Social Affairs of East Java Province, and Surabaya City Government. The direct governmental relation is started with the East Java Provincial Office for Social Affairs, in 1998-1999 through Social Security Network (JPS) and Rumah Singgah program. In 1999, the East Java Office for Social Affairs launched JPS program. At that time, the Foundation for Arek Lintang showed their openness to the governmental program. Just like the program received by Alang-Alang, later this kind of relationship become pragmatic relationship by putting NGOs as sub contracts of government programs. However, unlike Alang-Alang who received the program, Arek Lintang believes that the program is not in accordance with what is needed by the child labor, especially the street children and is not in-line with what Arek Lintang Foundation does. Furthermore, the foundation no longer accepts aid or participates in Rumah Singgah program.

Different action is given by Arek Lintang in their relation with Police Department. Many children go through the process of interrogation at the Police Department with physical violence, and this problem is engaged by Arek Lintang Foundation which then initiated the formation of Surabaya Children Crisis Center (SCCC). Together, they built a partnership with Polwiltabes (Police Department) of Surabaya to conduct training for police on how to handle children, both children involved in law deviation and children experiencing exploitation and violence, both sexual violence and domestic violence. This demonstrates that Arek Lintang Foundation cooperate and promote the development of child labor protection through direct collaboration with government actor. The first stream feature is also shown by the accommodation of joint needs by Polwiltabes Surabaya, which is even developed to some other area in East Java Province. This form of relationship is also no longer in the form of NGOs as sub contracts of government programs, but instead becomes the initiator of the child labor conservation effort with the government. Such relation is also in line with the conception of Philip Eldridge (1996) who argues that NGOs have an important network i.e. NGOs play an important role in information sharing, providing access to legal means and governance structures, media and other opinion-forming groups; NGOs are also capable of providing lobbying on issues of mutual concern like this training.

Meanwhile, LPKP shows that they are openly acts as a sub contract of government programs from the very beginning, both in terms of establishment with existing programs in line, and the orientation of NGOs that are in line with the government. This feature can be explained by Philip Eldridge's view in the model of government and NGO relationships in the first stream. In this regard, LPKP is also aware of the limitations of NGOs and governments in protecting child labor.

After looking at how the relation is going with every reaction and stance in every NGOs, some tendencies can be concluded as the figure below. From the government to NGOs, it shows that NGOs are still considered as the one running the government program and playing a sub contract role without mutual stance and needs. Meanwhile, the relationship from the NGOs to the government lies upon practical needs (need for birth certficate, etc.), advocacy for some cases, and collaboration initiatives. The picture below show how that relation goes.

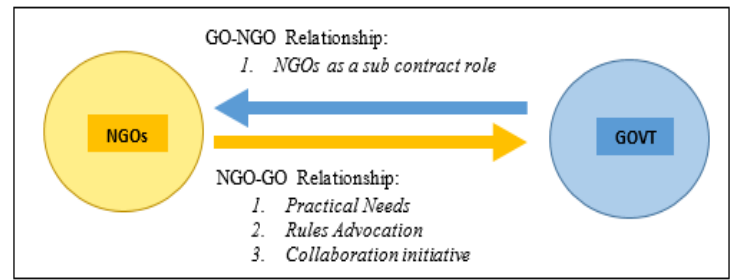

Fig. 1 Tendency of GO-NGO Relation

This tendency is also asymmetrical in government and NGOs relation in child labor protection program. The GO-NGO relationship places NGOs as a sub contract of government program, thus taking a bigger portion than the NGO-GO relationship. Meanwhile, the NGO-GO relation tends to show relationship built on practical needs and advocacy of their interests. This practical need is a need that directly touches the problem of child labor under its auspices. The examples are the experiences of Yayasan Alit and Alang-Alang in overcoming child labor problems by facing the hospital directly when a child is in need of emergency, and Population and Civil Registry in case of birth certificate. While the rest, the relationship of NGOs to the government is in the form of advocacy of interests in various forms. The form of complementary relationships and other supplements is shown in the form of collaborative initiatives such as those undertaken by the Arek Lintang through training on how to handle children arrested by Police Officers as previously described. This is in line with the opinion of Shanta (Shanta in APMAS, without years) that NGOs do not substitute governmental duties, but rather complement and supplement it. Furthermore, Shanta (Shanta in APMAS, without years) said that the NGOs are mobilizing and providing access to the community to access public services and needs, instead of serving as a substitute for government duty. However, the portion of implementation is still very small, compared to relationships as sub contracts of government programs.

\section{DISCUSSION}

\section{A. The Effect of Pragmatism and Sub Contract Relation between $G O-N G O$}

The sub contract relation showed in GO-NGO relation in East Java should be seen as more than just executor for the government program. NGOs are still considered to be government substitutes, not seen as supplements and compliments that drive the development of society at the lower levels and fulfill the weakness of the government to reach the children. The relationship formed tends to be pragmatic based on the need of government capacity fulfillment by using the program as a tool. This is in line with Philip Eldridge (1996) who views the relation between government and NGOs in Indonesia tends as being pragmatic and characterized by cooperation and conflict. Pragmatic relationships and the position of NGOs as sub contracts enable further impacts such as trapping government and NGO relationships in the form of donor-driven relationship in terms of who is financing and who spends the money. It can also lead to experiences of Arek 
Lintang during the cases of JPS and Rumah Singgah. Donordriven relation will lead to the emergence of fictitious NGOs depending on government funding.

Talking about this sub contract relation on child labor protection as has been shown, the context of government and NGOs themselves is important in order to examine what influence determines government and NGO relations in child labor protection in East Java Province. NGOs tend to be inspired by the vision and personal motivation of the founders and members on particular issues. The context is very much different from the context of the government. The government is filled with bureaucrats and politicians, causing the run of government depend on the political will of the policy-makers who execute the government. Political will is a political behavior that shows its willingness, motivation, and how to end up spending resources for that purpose. Furthermore, Mintzberg (Mintzberg in Treadway, 2005) says that political will represents the willingness of actors to expend energy in pursuit of political goals and is seen as a starting point in political behavior. As explained, this political will instantly determine elements of other governance such as how the budget amounts on issues, development priorities, and other elements. This is due to the limited resources owned by the government so there are alternatives than other alternatives. The choice of this alternative is also influenced by the political interests of the policy holders in office. Similarly, elements of the Government related to the protection of child labor in East Java Province is considered not free from political action.

This political will context then lead us to 'how strong child labor issue is to be prioritized by the government?' In fact, the issue of child labor is still considered as having low political support. Mintzberg (in Treadway, 2005) previously explained, this political will instantly determine elements of other governance such as how to budget on issues, development priorities, and other elements. Low political support could be shown by the non-priority budgeting and other forms of handling that still have not touched on all aspects of the main objective of protecting child labor rights. The Rumah Singgah program is only a temporary shelter for street children, and PPA-PKH is still very limited with 15 days of shelter provision and only give recommendations for child labor to return to school. The remarks of Ms. Yanti, East Java Provincial Office for Social Affairs staff mentioning that the limited budget in the social rehabilitation portion for street children has caused the limited efforts of the government in handling street children. The division of duties is also delegated to the District/City. Similarly, information from Mr. Farich, a staff of the Directorate for the Supervision of Women and Child Wok Norm, shows that government budget is actually reduced in the PPA-PKH effort this year. The number of shelters in 2017 is also reduced to only 7 shelters spreading across the coordination areas in East Java. In addition, the perspective of the government that does not place children as the main focus can also affect political will and implementation of child labor protection policies. This issue is used by academicians to assume that the government still perceives children's problems depending on how poverty and women issues are cleared first. This is justified by Anna Persson (2012) who sees policymakers as paying more attention to development and reforms of political will, that is like a 'silver bullet' in the face of weak development performance. Political will by Kosack (2009) is also seen as government dependency not on everyone, but on people capable to support the needs of the government called vital constituent, some that the government cannot continue without. As long as child labor issue has not been an issue of vital constituents and development concerns, it will be difficult to make child labor protection a political priority for governments. As proposed by Jan Kooiman (2003) that the government's need to perform an objective has implications for the shift of government tasks and a high awareness of the need to cooperate with other societal actors and make intervention by the government, an intervention that is obsolete. Furthermore, this GO-NGO relation in East Java supports Jan Kooiman's argument that social-political or interactive governing will be considered to be arrangements in 'which public as well as private actors aim at solving societal problems or create societal opportunities, aim at the care for the societal institutions within which these governing activities take place, and phrasing the principles according to which these activities are carried out.

\section{B. GO-NGO Relation on Child Labor Protection in East Java: The Need of Shifting from Domestic Issue to Public Issue Movement}

The GO-NGO relation on child labor protection in East Java which is a pragmatic and sub-contract-based relation, is affected by its context as has been explained. This relation is made of the weak political will from the citizen and the asymmetrical relation of government with the NGOs. When analyzed with the concept of Uri Brofenbenner (1979) of the social ecology of the child, this condition is truly less beneficial for the child labor itself. Based on the hierarchical actor in the child environment, figure 2 below shows the position of the child labor, both in informal and formal sectors.

Fig. 2. Social Ecology of Child Labor in the Hierarchy of Influence; Informal child labor (left), formal child labor (right)
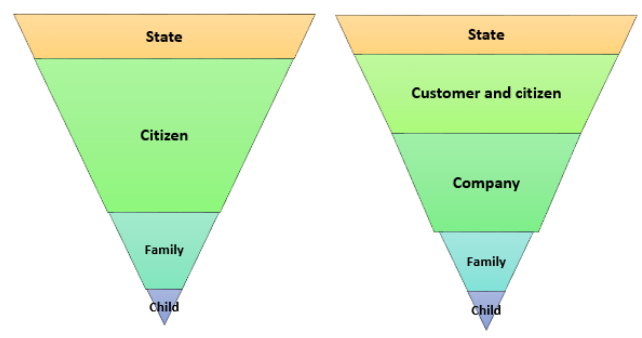

Through the social ecology analysis, it can be seen that the role of family in child labor protection is still dominant because family is the closest environment that could affect children. It is also supported by the stigma within society and the government that sees child labor as a domestic issue and entirely under the authority of family. This is explained by the academic informant who analyzes that the government until now eradicate more by giving charity such as scholarship, yet do not see that children in poor family have economic value by which child labor can produce more earning than the government provides. Emphasizing more on child power in this family, interventions should be made to prevent the market from accepting child labor so that families stop sending their 
children to work field in the society. In this case, social ecology of child labor in formal and informal sector work is different and has a hierarchy of suppressor groups respectively.

Social ecology in the context of child labor becomes an influential group capable to suppress the groups below it. Child labors such as street children, economic incentives, and lack of childcare capacity in Very Poor Households (RTSM) in urban areas encourage families to see children as having economic value and the streets still becomes a market for those children. As long as the streets provide the income for child labor, children still have economic value and families can choose to let their children work. While in child labor in formal sector, the role of companies and costumers and society as a pressure group becomes an influential group. Child labor in formal or related sectors is characterized by the work that contains the relationship with the formal industry i.e. the company. As long as the company does not accept and supervise its employees in all its distribution chains, families cannot place their children to work in this sector. Further it is shown by the figure above.

Therefore, the direction of GO-NGO relationships should shift and be specific to the circle above the children. This then points to the importance of government and NGOs to encourage other secondary groups in the community, directly related to the family in order to provide child labor protection that addresses the child directly. The covert nature of child labor can be addressed by making communities and families an 'eye' and 'hand' to overcome the limitations of government and NGO capacity in child labor protection. This encouragement of community groups will also encourage other socio-economic actors to work together and encourage greater political will so that child labor issues can be resolved soon. This also supports Jan Kooiman who argues the contexts on the borderline between the social and the political: the borderline between state, market, and civil society cannot be handled by each of these realms in isolation. Their character and nature are such that they 'trespass' the traditional boundaries separating them. This means that governing them requires the images, instruments, and action potential for the three parties to solve them (if they can be solved at all) or at least, not to let them run out of control on account of their own complexities, diversities, and dynamics. It is necessary in this context for governments and their social partners to mark out their mutual responsibilities, jointly, and continuously. This mutual responsibility would appear when child labor in East Java is considered as public issue and public responsibilities, instead of mere domestic issue.

\section{CONCLUSION}

The relation of the government and NGOs in child labor protection on East Java shows a tendency of pragmatic relation and places NGO at sub contract role. This condition is affected by the lack of political support within the government and the society. Furthermore, it is known that one of the main problems of GO-NGO relation on child labor protection is the need of shifting child labor issue from domestic issue to public issue; the society circle above the child is also important to build a social-political interaction beneficial for the child labor.

\section{REFERENCES}

[1] APMAS. (no year). A Report on State and Districts Level Workshops. Andhra Pradesh: Mahila Abhivruddhi Society

[2] Bronfenbrenner, Urie. (1994). Ecological Models of Human Development. International Encyclopedia of Education, Vol. 3 2nd. Ed. Oxford: Elsevier, dicetak kembali di Gauvain, M. \& Cole, M. (Eds.). (1993) Readings on the Development of Children, 2nd Ed. New York: Freeman.

[3] Dol.gov, 2014. 2014 Findings on The Worst Form of Child Labour. https://www.dol.gov/agencies/ilab/resources/reports/childlabor/indonesia, diakses 15 Maret 2017.

[4] Eldridge, Philip. (1996). Development, Democracy, and Non-Government Organizations in Indonesia. Asian Journal of Political Science, 4:1. 1735. http://dx.doi.org/10.1080/0218537960843070

[5] Fakih, Mansour. (1991). NGOs in Indonesia: Issues in Hegemony and Social Change.. Occasional Paper Series on Non-Governmental Organizations http://scholarworks.umass.edu/cie ngo/2,

[6] International Labour Organization. (2004). Bunga-Bunga di Atas Padas: Fenomena Pekerja Rumah Tangga Anak di Indonesia. Jakarta: ILO CoOffice Jakarta.

[7] International Labour Organization. (2011). Kajian Terhadap Peraturan, Kebijakan, dan Program-Program Penghapusan Pekerja Anak di Indonesia. Jakarta: International Program on the Elimination of Child Labor (IPEC).

[8] International Labour Organization. (2012). Social Protection Assessment Based National Dialogue: Towards A Nationally Defined Social Protection Floor in Indonesia. Jakarta: ILO Co-Office Jakarta.

[9] JARAK. (2010). Satu Dasawarsa Mengembangkan Aksi Penghapusan Pekerja Anak: Hasil Monitoring Pelaksanaan Konvensi ILO 138 dan 182 di Indonesia.

[10] Komite Aksi Nasional PBPTA. (2007). Laporan Pelaksanaan RAN PBPTA Tahap Pertama (2002-2007). Jakarta: Sekretariat KAN PBPTA.

[11] Komite Aksi Nasional PBPTA. (Tanpa Tahun). Laporan Pelaksanaan RAN PBPTA Tahap Pertama (2002-2007) dan Rencana Aksi RAN PBPTA Tahap Kedua (2008-2012). Jakarta: Sekretariat KAN PBPTA.

[12] Kosack, Stephen. (2009). Realising Education for All: defining and using the political will to invest in primary. Comparative Education, Vol. 45, $\begin{array}{lllll}\text { No. } 4 \text { (NOVEMBER 2009), pp. } & \end{array}$ http://www.jstor.org/stable/40593192

[13] Kooiman, Jan etc. (2003). Demokratien in Eropa. Wisbaden: VS Verlag für Sozialwissenschaften, Wiesbaden

[14] Perrson, Anna; etc. (2012). Responsive and Responsible Leaders: A Matter of Political Will?. Perspectives on Politics, Vol. 10, No. 3 (September 2012), pp. 617-632. Published by: American Political Science Association. http://www.jstor.org/stable/23260182, diakses 9 Juni 2017

[15] Santrock, J. W. (2011). Educational Psychology. New York: McGraw Hill.

[16] Senbeta, Hailu Abey. (2003). Non Governmental Organizations and Development with Reference to the Benelux Countries. Belgia: Université catholique de Louvain.

[17] Treadway, Darren C, etc. (2005). Political Will, Political Skill, and Political Behavior. Journal of Organizational Behavior, Vol. 26, No. 3 (May, 2005), pp. 229-245. http://www.jstor.org/stable/4093939 